\title{
The Rest is Silence: Postmodern and Postcolonial Possibilities in Climate Change Fiction
}

\author{
Adeline Johns-Putra \\ [forthcoming in Studies in the Novel, 2018]
}

Climate change is one of the most prominent symptoms of an age of unprecedented human impact on the biosphere - the age sometimes called the Anthropocene. In identifying humanity as a geological agent, the term "Anthropocene" exposes the fallacy of human exceptionalism, reminding us of the entangled nature of human and nonhuman agency, and the vast and decidedly nonhuman proportions of human action. For, as climate change and other Anthropocene events make clear, the effect of humans on their environment will far outlast human dimensions of individual lifetimes and even historical epochs: some of the impacts of humans' activity—for example, species depletion—are irrevocable; others, such as polar ice-melt, are reversible (if at all) over immense durations of time. But in its recognition of the imbrication of human action with the biosphere (in all its human and nonhuman complexity), the concept of the Anthropocene captures a profoundly and existentially disturbing paradox. That is, even as we must confront the damaging illusion of human agency existing aloof and apart from nonhuman "nature," we must also consider how to recuperate a nuanced view of human agency that enables humans to engage more fully with the unprecedented crisis now engulfing human and nonhuman organisms and environments. ${ }^{1}$

Yet, that increasingly popular cultural response to the Anthropocene-climate change fiction — has so far tended to adhere to firmly anthropocentric conventions. Timothy Clark, in Ecocriticism on the Edge (2015), finds that the novel's penchant for realism means that it offers an impoverished view of the world, with the immediacy, individualism, and intimacy 
of its perspective standing in stark contrast to the enormity of the impact of human actions and behaviors now being disclosed in the Anthropocene. As I read it, Clark's critique is, in effect, a call for a dose of radical self-reflexivity if fiction is to have relevance as a form of (human) expression in a climate-changing world.

In this essay, I speculate on the extent to which this call is being met. Specifically, I speculate on the dawning of a postmodern sensibility in climate change fiction. I thus explore the possibilities raised by two recent novels for an emerging postmodern awareness of the limitations of realist fiction's anthropocentric perspectives in the Anthropocene. While it might seem that climate change fiction has come rather late to the postmodern party (which has, after all, been going on for decades), I would argue that postmodernism—defined, in Jean-François Lyotard's pithy phrase, as “incredulity towards metanarratives" (xxiv)—now possesses a peculiar urgency and relevance, considering the damage done by the metanarratives of the Anthropocene. The two novels I discuss-Alexis Wright's The Swan Book (2013) and Chang-rae Lee's On Such a Full Sea (2014) — are definable as climate change novels inasmuch as they are set in a future world ravaged by climate change. They are postmodern in their sensibilities inasmuch as they question the dominance of masternarratives. They are also postcolonial in their identification of this dominance as both a cultural and a speciesist imperialism. That is, Wright's and Lee's novels destabilize the primacy of what Val Plumwood labels the "hegemonic centrism" of "[d]ominant western culture," which is "androcentric, eurocentric, and ethnocentric, as well as anthropocentric" (Environmental Culture 101) all at once. For Plumwood, "hegemonic centrism" designates the discursive maintenance of a white, masculine, human perspective at the center of power, and describes the ways in which the pervasive belief in human entitlement coincides with historical patterns of political mastery. In these novels, I argue, such a perspective is dislodged by a range of postmodern strategies. Indeed, since domination per se is questioned, 
as the dominant perspective- - whether that of an omniscient narrator or other focalizing agents - is placed under erasure. Voice itself comes under suspicion. In other words, I argue, ultimately, for the significance of narrative silence as a radical response to and revision of fiction's anthropocentric biases.

Before discussing Wright's and Lee's novels, I briefly consider the prevalence of realist conventions in climate change fiction, exploring further, among other things, Clark's insistence on a critical awareness of the novel's anthropocentric tendencies. I then explore the term "postmodernism"; though the concept is a familiar one, it is useful to highlight the characteristics most relevant to my analysis and to explain their continuing relevance to new developments in climate change fiction. In the light of these novels' emphasis on colonial experiences of marginalization, I also consider the relationship of postmodern literary strategies to postcolonialism, and especially to ecocritical strands of it. I then turn to Wright's and Lee's novels; while I hesitate to claim that these herald a distinct postmodern turn in climate change fiction, I do wish to argue that these novels, both published within the last five years, show a postmodern self-awareness that constitutes a promising new direction for fiction in the Anthropocene.

\section{Realism in the Anthropocene}

Because the Anthropocene signifies not just the embeddedness of human activity in the nonhuman environment but its effects at scales far beyond what has hitherto been imagined, Clark suggests that it results in what he terms "Anthropocene disorder" (139), in which the placing of thoughts and acts in human-to-human terms, once so relevant, no longer does justice to the human condition. If the Anthropocene constitutes a challenge to conceptualizations of human ontology, it presents, equally, a challenge to human expression. Clark speculates that the Anthropocene forms "a threshold at which art and literature touch 
limits to the human psyche and imagination themselves" (176); that is, art, particularly literary art, is virtually impossible in the existentialist impasse in which we find ourselves. In response to propositions, such as Timothy Morton's (159-201), that some art-most often, the avant-garde - has the potential to shock or immerse humans into a properly ecological worldview, Clark expresses a degree of skepticism. He particularly finds that this is pointedly not the case with the climate change novel. Where experimental forms of art might be considered to be likely sites of subversion or resistance of expectations of subjectivity and identity, the novel, as Clark points out, is a remarkably conventional art-form, relying on and in turn reproducing those very expectations. "Linguistic narrative in particular," writes Clark, "seems at issue solely as that mode which ... fits least well into the demands of the Anthropocene, seemingly more allied with forms of anthropocentric thinking to be overcome, or as an art of sequences of human action or attention geared to a definite significant end in some fulfilled or unfulfilled intention" (187). For Clark, the "still-dominant conventions of plotting, characterization and setting in the novel [are] pervaded by anthropocentric delusion" (164-65).

To be sure, so far, climate change fiction has hardly effected the kind of wholesale subversion of subjectivity Clark so desires. Adam Trexler's recent survey of the phenomenon, Anthropocene Fictions (2015), draws on a substantial corpus of climate change novels (see Trexler and Johns-Putra, 185-200). Interestingly, Trexler argues that climate change (with its composite make-up, emergent properties, and unpredictable agency) has forced the contemporary novel to abandon some of its conventional strategies; yet, even he describes, in the final analysis, "the rise of realist fiction about the Anthropocene" (233). Indeed, taken together, the climate change novels surveyed by Trexler reveal a tendency to employ highly conventional literary strategies of world-building and character development, even — or, one might say, especially — in cases where climate change fiction tends toward 
futuristic scenarios. Sylvia Mayer usefully distinguishes between climate change novels that are set in the future and those that are set in the present, the former drawing imaginative appeal from catastrophe and the latter from anticipation (21-37). Both depend on profoundly traditional and anthropocentric expectations. Certainly, this is more obviously the case with climate change fiction that invokes a recognizable present (or very near future) in which the threat of climate change poses an ethical, political, or economic dilemma —or, more often, a combination of these-for the individual. Yet, it is worth noting that futuristic climate change fiction is also anthropocentric in its way. After all, it is indebted to the generic conventions of science fiction and its traditions of building strange, but nevertheless internally consistent, environments, which characters inhabit and into which readers enter. ${ }^{2}$ In Darko Suvin's nowauthoritative analysis, the creation of a novum — a new but cognitively logical and coherent setting - is a special characteristic of science fiction (63); in Tom Moylan's evocative description of the expectation that this generates, "the experienced sf reader moves through a text like a traveler in a foreign culture or a detective seeking clues to unravel the mystery at hand" (7). In both of Mayer's broad categories, then, climate change fiction displays a predilection for highly conventional and canonical novelistic techniques grounded in dominant perspectives.

Thus, though scholars such as Trexler and, more recently, Antonia Mehnert have argued that "writers come up with innovative narrative means to overcome the elusiveness of climate change" (Mehnert 16), the Anthropocene appears not to have had so radical an effect on the novel, ontologically speaking. As Clark's considered analysis_-including his response (179-82) to Trexler's study—suggests, not just literature but also literary critique in the Anthropocene remain committed to notions of subjectivity, to the "intelligible and coherent world at the personal scale, centred on individual agency" (165). Clark astutely argues that, even where critics demonstrate climate change fiction's innovations in representing climate 
change as a complex phenomenon, their discussions of representation (innovative or otherwise) ultimately depend on conventional and anthropocentric expectations of narrative stability and reliability. In other words, the climate change novel has not appeared to have utilized, in any systematic way, the strategies of postmodernism, which provide the most obvious means of de-centering or eliding human agency from fictional narrative.

\section{Postmodernism in the Anthropocene}

With Lyotard's germinal description of postmodernism's “incredulity towards metanarratives" as a starting point, one can define postmodern literature as literature that takes just such a suspicious approach to long-standing assumptions to do with "reality," "history," and "truth." In Bran Nicol's explication, "the most important features found in postmodern texts" are: "a self-reflexive acknowledgement of a text's own status as constructed, aesthetic artefact"; "an implicit (or sometimes explicit) critique of realist approaches both to narrative and to representing a fictional "world"'; and "a tendency to draw the reader's attention to his or her own process of interpretation as s/he reads the text" (xvi). This sense of self-critical and cynical commentary on the constructedness of text and the roles of author and reader in propagating such a construct emerges in particular as metafiction - "the main technical device used in postmodern fiction" (Nicol 35). Metafiction describes, according to Patricia Waugh, "fictional writing which self-consciously and systematically draws attention to its status as artefact in order to pose questions about the relationship between fiction and reality" (2). Specifically, suggests Waugh, this attentiondrawing is conducted through the self-critique of the novel's "ordered reality," a reality expressed through, among other things, "well-made plot, chronological sequence, the authoritative omniscient author" (7). That is, to return to Lyotard, the postmodern incredulity towards metanarratives expresses itself microcosmically in postmodern fiction as an 
incredulity towards narrative itself and thus towards its trappings, namely, organized, linear plot and reliable, coherent points of view.

A mistrust of realism is also the dominant characteristic of the related postmodern phenomenon of magical, or magic, realism. Magical realism is sometimes discussed as an important subset of the postmodern, described, for example, as "a strong current within the stream of postmodernism" (Faris 165). It is often viewed as a postcolonial manifestation of postmodernism: indeed, Stephen Slemon's influential analysis characterizes it specifically as "post-colonial discourse" (9), with magical and realist worldviews mapped onto those of colonized and colonizer. As Slemon states, "the magic realist narrative recapitulates a dialectical struggle within the culture's language, a dialectic between 'codes of recognition' inherent within the inherited language and those imagined codes - perhaps utopian or futureoriented - that characterize a culture's 'original relations' with the world" (9).

Magical realism may not be an immediately obvious vehicle for interrogating anthropocentrism, since it is itself open to accusations of instigating a cultural commodification that closely resembles the metanarrative of human exceptionalism that characterizes the Anthropocene. From the outset, it has been critiqued by some for fetishizing the colonized other in primitivist terms; Jean Franco, for example, famously complained that it is "little more than a brand name for exoticism" (21). Yet, such criticism risks repeating the very reductionism it seeks to condemn, for its trenchancy depends on reading magical realist texts as rather simple representations of their particular cultural milieus, which work either naïvely to celebrate these worldviews as magical or cynically to market them as such. Instead, as more recent studies of magical realism have argued, the phenomenon is worth studying for its formal—rather than "socio-cultural or geo-political” (Aldea 17)— characteristics. Thus, Christopher Warnes argues that "magical realist novels are deliberate, carefully contrived and manipulated works of art rather than unmediated conduits of cultural 
values and perspectives" (11). Moreover, to "rescue the term magic from its relegation to the domain of the illusionary, the primitive and the childish" (Warnes 8) is to recognize that such manipulations are thoroughgoing critiques of the notion of a singular reality rather than instances of intellectually immature or disingenuous self-indulgence. In Warnes's definition, magical realism is "a mode of narration that naturalises or normalises the supernatural; that is to say, a mode in which real and fantastic, natural and supernatural, are coherently represented in a state of equivalence. On the level of the text neither has a greater claim to truth or referentiality" (3). As Eva Aldea suggests, the hallmark of magical realism is “difference” (18) itself. In Warnes's and Aldea's formulations, then, magical realism strives to expand our definition of reality, by questioning our commitment to a dominant Western, Enlightenment version of it as strictly rational and causal.

These explorations of magical realism echo Theo D'haen's influential analysis of magical realism as that strand of postmodernism that expresses a cynicism toward the center. Citing magical realist novelist Carlos Fuentes's realization that "there were no centers of culture, race, politics," D'haen remarks that "[i]t is precisely the notion of the ex-centric, in the sense of speaking from the margin, from a place 'other' than 'the' or 'a' center, that seems to me an essential feature of that strand of postmodernism we call magic realism" (194). That is to say, magical realism's alternative discourse of the fantastical is an explicit critique not just of the center, but of the idea that there can be a center.

Both the metafictional and magical realist impulses of postmodernism, then, can be construed as critiques of dominant political and cultural ideologies - and, indeed, as critiques of the very notion of ideological domination. They achieve this through a corresponding critique of what one could think of as narrative or perspectival singularity. According to Waugh, metafiction not only arises out of an awareness of the provisionality of "history and reality" (7); it interrogates the "social institutions" (11) that shore up the illusion of their 
stability by, in turn, denying the representation of narrative stability: postmodern metafiction originates in "the notion that 'everyday' language endorses and sustains such power structures through a continuous process of naturalization whereby forms of oppression are constructed in apparently 'innocent' representations" (11). Similarly, D'haen finds that magical realism offers the possibility both for postcolonial writers to eschew "the views of the hegemonic forces together with their discourse" and for "Western" writers to "dissociate themselves from their own discourses of power, and to speak on behalf of the ex-centric and un-privileged" (195); importantly, the political challenge to the hegemonic power of the center is, at one and the same time, a representational challenge. Thus, writes D'haen, "magic realist writing achieves [its] end by first appropriating the techniques of the 'centr'-al line and then using these ... to create an alternative world correcting so-called existing reality, and thus to right the wrongs this 'reality' depends upon" (emphasis in original, 195). Crucially, then, with these postmodernist strategies, any subversion involves steady interrogation rather than outright disregard of realism and, with it, "reality." Metafiction "explicitly lays bare the conventions of realism; it does not ignore or abandon them" (Waugh 18), while magical realism often "seeks to critique the claims to truth and coherence of the modern, western world view by showing them up as culturally and historically contingent" (Warnes 13). That is, metafiction sheds light on the artifice of realism, and magical realism confounds it with its supposed opposite.

Thus, what metafiction and magical realism open up in the Anthropocene is the opportunity to critique (in Waugh's terms, to expose and, in D'haen's terms, to “de-center") the norms and expectations around realism, and, moreover, to align this with an exposé and de-centering of what, after Plumwood, one might view as the hegemonic centrism of human exceptionalism. This is not to say that climate change fiction has been utterly devoid of postmodernist tendencies. For example, Margaret Atwood's "MaddAddam” trilogy (Oryx 
and Crake, 2003; The Year of the Flood, 2009; MaddAddam, 2013) displays in full flow the author's penchant for pastiche and parody: its dystopian setting is a bricolage of allusions to existing cultural and scientific trends and objects, exaggerated in order to mock and critique contemporary consumerist and bioengineering obsessions. More obviously postmodern, particularly in its narrative structure, is Jeanette Winterson's The Stone Gods (2007), whose non-linearity, multiple storylines, and fantastical sense of temporality in terms of form and structure are mirrored in the plot by an ethos of openness towards others and the transgression of human-nonhuman boundaries. Its narrative hybridity thus offers a pointed alternative to an anthropocentric hegemony. Indeed, Winterson's novel could be said to be the first significant climate change novel to experiment with narrative technique as part of a concerted critique of human exceptionalism, a trend that Lee's and Wright's novels continue, with a particular emphasis on colonial and environmental (in)justice.

The critique of environmentally destructive practices through a consideration of colonial power is, of course, not new. Postcolonial ecocriticism has identified how the project of imperialism and the ideology of racism on which it depends have facilitated the domination of both racial and nonhuman others in the name of conquest and civilization: “Once invasion and settlement had been accomplished," write Graham Huggan and Helen Tiffin, "the environmental impacts of western attitudes to being-in-the-world were facilitated or reinforced by the deliberate (or accidental) transport of animals, plants, and peoples throughout the European empires, instigating widespread ecosystem change under conspicuously unequal power regimes" (6). Postcolonial ecocriticism has thus sought to shed light on what Deane Curtin calls "environmental racism"; that is,

the connection, in theory and practice, of race and the environment so that the oppression of one is connected to, and supported by, the oppression of the other. In simple terms, in a culture that damages nature there is a tendency to 
reinforce this by connecting certain people with nature so that they can be "naturalized." Conversely, in a culture that oppresses certain groups of people, there is a tendency to connect these groups with justifications for damage to nature. (145)

At the same time, and moving away from concepts of race per se, some scholars have advocated the wholesale decolonization of the now-ubiquitous worldview of "Western anthropocentric colonial ecologies," in particular the dismantling of its stringent "nature/human divisions" (Demos 23), which Plumwood originally identified as part of a deeply entrenched hierarchical dualism - “an intense, established and developed cultural expression of ... a hierarchical relationship, constructing central cultural concepts and identities so as to make equality and mutuality literally unthinkable" (Feminism 47).

The strategies of postmodern fiction allow such decolonizing impulses to be embedded in literary form. To destabilize the methods and techniques of realism is to recognize the fallacy of a coherent center and to blur the hard and fast lines between culture and nature, human and nonhuman, truth and fantasy. I read this in turn as part of a larger project to dislodge the kind of binaristic thinking, emanating from Western modernity, that the metanarratives of reality, anthropocentrism, and cultural domination have in common. The novels I now go on to explore display a suspiciousness towards hierarchies, boundaries, and centeredness, in tandem with a critique of the realist concern with a dominant point of view as a stable ontological ground. In particular, these novels utilize silence as a strategy; they undermine the omniscience of third-person narrators and the reliability of focalizers, in a move that simultaneously interrogates realist, imperialist, and anthropocentric constructions of the world. 


\section{The Swan Book and On Such a Full Sea: De-Centering Anthropos, De-Centering Voice}

Wright's fiction, as Kate Rigby deftly identifies, is profitably read within a "poetics of decolonization" (120-36). Like Wright's earlier Carpentaria (2006), The Swan Book is set in Australia, in this case in the late twenty-first century, when the world has been ravaged by climate change: "Towns closed, cities were boarded up, communities abandoned, their governments collapsed" (8), while "Mother Nature" is better described as "Mother Catastrophe of flood, fire, drought and blizzard. These were the four seasons which she threw around the world whenever she liked" (8). Australia's Aboriginal population suffers not only from these natural disasters but from centuries of dysfunction as a result of internal colonialism. A young Aboriginal girl, traumatized by gang-rape, runs away from her community, a lake settlement based on Wright's own Waanyi nation in northern Australia (Holgate 636). The treatment of this government-controlled community of Aboriginal Australians has clear echoes of Australia's history of state interference into Aboriginal affairs, including the 2007 Northern Territory National Emergency Response, informally called "the intervention," which saw the Army take possession of seventy-three Aboriginal communities on grounds, subsequently disproved, of widespread child abuse and neglect (Takolander 115). The girl conceals herself in the hollow of a sacred tree until she is found by a white woman called Bella Donna. Bella Donna, a climate refugee from the West, christens the girl "Oblivia" and takes her in. Oblivia's upbringing is thus marginal to both wider Australian culture and the Aboriginal community in which she was born. This marginality is emphasized rather than erased when she marries Warren Finch, a man from the same community raised to be the country's first Aboriginal president. After being feted as his promised bride and married in an elaborate ceremony, Oblivia is imprisoned by Warren in a tower in one of the country's southern cities. 
Oblivia, clearly, belongs to a community disempowered by both imperialist brutality and ecological degradation. When their settlement is turned into a camp for asylum-seekers and refugees' boats are dumped in the lake, and after sand storms raised by climate change transform the lake into a marsh, the "lake people" (12) are rendered "[s]wamp people" (22). What is more, the alignment of racial with environmental exploitation is crystallized in Oblivia's special affinity with the nonhuman. She makes a special connection with the lost black swans that descend on the swamp. The swans, native to Australia's south, have been displaced by global warming, an analogy with the spiritual dislocation of Oblivia's community, whose connection to the land is severed both by the Army's use of it as a dumping ground and by the effects of climate change. Oblivia, doubly displaced from country and community, becomes aware of a particular connection in her first encounter with a lost black swan: "She knew for a fact that the swan had been banished from wherever it should be singing its stories and was searching for its soul in her" (15).

Perhaps most importantly of all, Oblivia is marked not just by powerlessness but by voicelessness. She has been rendered mute by the trauma of her rape by a gang of local boys - a crime that the novel explicitly correlates with state mistreatment and mismanagement of Aboriginal youth, the boys "given a fresh start by a youth worker" and "largesse to close the gap of failed policies for Aboriginal advancement from the Government in Canberra" (84). Oblivia's muteness is associated with an alternative reality or, indeed, temporality, for the experience of rape brings with it a rupture in time that is also expressive of a rupture in Aboriginal history - in other words, a transgression of its Dreamtime or cosmology. In Bella Donna's view, Oblivia has been "gang-raped physically, emotionally, psychologically, statistically, randomly, historically, so fully in fact: Your time stands still" (emphasis in original, 82). Thus, Oblivia's violation is a synecdoche for the violation of Aboriginal country, people, and ontology. Indeed, Oblivia's subsequent concealment of 
herself in the sacred tree emphasizes her connection to native land and belief at once. That she exists in a magically vegetative state-"[1]ocked in the world of sleep" (7)-establishes her place both in an ecological network and within an Aboriginal Dreamtime. Wright herself has suggested that the alternative ontology of the Dreamtime grants to Aboriginal people a particular understanding of time on an ecological scale: describing "Indigenous memory," she writes, "men and women can name and tell the story of individual sites in their country, continuing a long tradition of watching over this country and maintaining the ecologically sustainable life” (“A Question of Fear” 135). Thus, Oblivia's tree is, simultaneously, a place of refuge for her, a source of reconnection to the nonhuman (for, within her dreamlike state, her fingers trace a "ghost language" [8] on its bark), and a site so sacred to her people it is "like all of the holiest places in the world rolled into one for us" (78).

Oblivia's silence creates something of a vacuum for other voices to fill. Since her muteness is linked to an alternative, ecocentric reality, the voices it opposes are representative of what is conventionally accepted as "reality" in anthropocentric and Eurocentric terms. That is, in line with the possibilities opened up by magical realism, the magical alternative challenges the version of history emanating from what D'haen describes as the ideological or cultural center and what Plumwood designates as hegemonic centrism. Bella Donna's desire not only to "rectify the problem of the speechless child" (20) but "to get the girl to act normal" (21) recalls the enforced acculturation of Aboriginal Australia by successive white Australian governments. Maria Kaaren Takolander notes that "Bella Donna not only 'discovers' Oblivia, just as white Australians are said to have discovered their continent, but also sets about saving her from her people's ways in a way that ironically resonates with the treatment of Aboriginal people throughout Australia's colonial history" (113-14). In this, the old woman's whimsical stories of her travels, mixed in with European poetry and folklore, represent not so much the expression of an alternative reality on a par 
with the girl's as the imposition of a canonical white culture. Indeed, that Bella Donna's tales revolve around European white swans rather than the native black swans so central to the girl's sense of Aboriginal selfhood only underscores this, and speaks to ecological as well as cultural invasion.

Even more insidious, however, is Warren Finch, whose indigenous origins combined with political power mean that he straddles the alternative reality betokened by Oblivia and her people on the one hand (their Dreamtime) and the realpolitik of a dominant or centrist ideology on the other ("the grey-coloured politics far-away in Canberra" [47]). Warren is able to cross between the two realities, as when he switches off his ubiquitous mobile phone in order to undertake a days-long walk with Oblivia and his advisors, an immersion in a temporal lacuna that brings to mind the Aboriginal initiation custom of temporary mobility commonly known as "walkabout" and still little understood or accounted for by Australian government policy (Biddle and Prout 305-26). But Warren is no Aboriginal hero. That he has embraced a mode of power and discourse expressive of both environmental and racial injustice is readily apparent in his abduction and imprisonment of Oblivia, and his subsequent destruction of her community; his anthropocentric and imperialistic power is figured in the black swans that become entrapped in Oblivia's city apartment with her.

Importantly, then, Warren's biculturalism figures him as an assimilated other. Assimilation here highlights the insidiousness of colonial power. For the novel's juxtaposition of magical and conventional realities is no simple opposition of colonized and colonizer, but a complex battle between colonized and a profound and therefore dangerous colonial ideology. As Ben Holgate perceptively suggests, Wright's novel necessitates a restatement of Slemon's analysis of magical realism as involving "two oppositional systems" of "colonized and colonizer" (635); Holgate argues instead that magical realist fiction such as Wright's "incorporates three oppositional systems: the Indigenous colonized; the white settler 
colonizer; and global economic forces that help perpetuate the colonization" (635). One could add, considering the climatic dimensions of Wright's dystopia, that these forces are also aligned with destructive anthropocentric ideologies that enable disasters such as climate change. As Takolander comments, Wright's "vision of colonial trauma is both vast and personal, incorporating environmental devastation ... and the intimate suffering of Aboriginal children" (113). Warren emerges, then, as a signifier of the sheer portability and hence hegemonic power of an environmentally and socially destructive imperialist ideology. His consent to cultural assimilation means that he is complicit in a position not just of white exceptionalism but human exceptionalism, and is a particularly dangerous harbinger of racial and environmental aggression.

In Wright's novel, Oblivia demonstrates an affinity not just with the alternative temporality and reality associated with her people's ancient beliefs, but specifically with the nonhuman environment that sustained those beliefs and that has been violated by successive white governments. All this is of a piece with her silence, a silence that means that, unlike Warren, she resists the discourse of anthropocentric and Eurocentric power. Similarly, Fan, the protagonist of Lee's On Such a Full Sea, belongs to a community marginalized on the basis of race, with this marginalization correlated with ecological devastation; Fan, too, is defined by a voicelessness that signifies not so much powerlessness but the subversion of power.

On Such a Full Sea is set several centuries in the future, in a world of scarce resources, rampant pollution, and failing governments. In the United States, private corporations, known as Charters, have set up residential enclaves for the wealthy, while indenturing foreign workers from Asia to produce fresh, uncontaminated food for Chartered villages. The novel is the story of Fan, a young woman from the Chinese labor colony of BMor, built on what used to be Baltimore. Fan begins the narrative as a cog in the wheel of 
corporate imperialism, her life regulated and controlled by the powerful Charters. Climate change is part of this dystopian picture: food scarcity is brought on partly by global warming; B-Mor is affected by annual floods from Atlantic hurricanes; and, tellingly, mid-September is acknowledged to be "the heart of summer" (79). Another permanent feature of this dystopia is terminal illness, in the form of cancer brought on by humans' tinkering with the food chain, in terms of both environmental pollution and genetic modification. Everyone is doomed to die from a disease referred to as "C" (104): “[n]obody goes C-free" (101) and there is "no blanket prevention, no inoculation, no ultimate cure" (104). When her boyfriend, Reg, goes missing, pregnant Fan escapes from B-Mor to search for him. She chances upon her long-lost brother, Oliver, who has been relocated to a Charter village as a child because of his academic ability. Oliver agrees to help Fan, but, when he discovers that Reg has been taken away to be tested because he is C-free, he tries to turn her over to the Charter authorities in return for monetary reward. It is only with the help of Oliver's wife, Betty, that Fan narrowly escapes at the very end of the novel.

As with Oblivia, Fan is intimately connected to her nonhuman environment. The exploitation of natural resources by the Charters is mirrored by the regulation of the B-Mor workers: the fish, fruit, and vegetables, along with the laborers who husband them, are modified and manipulated by the Charters. Thus, the divers who manage the tanks and feed the organic fish for which B-Mor is famous must learn to work without breathing equipment: because "[f]earful fish are not happy fish," the diver "is part of the waterscape from the time they are hatchlings" (4). Strikingly, Fan displays an extraordinary affinity with the water and "almost preferred being in the tanks than out in the air of B-Mor" (6); even more strikingly, she poisons her fish before leaving them, an act ostensibly inexplicable-described simply as "not fathomable" (11) — but comprehensible by the end of the novel as a refusal to submit to the demands of Charter consumerism. 
Like Oblivia's muteness, Fan's seeming passivity ultimately reveals how the colonized other might be assimilated into — but, equally, might resist—a discourse that is both culturally imperialistic and anthropocentric. Though Fan herself demonstrates a considerable amount of agency in the novel, she is conspicuously absent as a focalizer for her own actions. Instead, the novel's point of view originates in a narrator whose constant use of the plural "we" and loyal explanations of B-Mor's system of values suggests a disembodied community spirit rather than a conventional, third-person, omniscient narrator. In Lee's own analysis of his novel, this mysterious narrative "'We' can be anything from a sort of chorus, omniscient and perhaps moralizing, to something more particular, even 'individual' in sensibility, with biases and desires, or can at times seem confused and unreliable, or else sustained by pure hope and conjecture" (qtd. in Leyshon). Certainly, the unexplained narrative voice, with its sympathy for Fan's audacious escape combined with a half-hearted insistence on repeating BMor worker slogans_- “Save some noodles for tomorrow's lunch" (52) or "Ensure the input to ensure the output!" (100)—soon establishes itself as unreliable, and hence creates an ironic awareness that all is not what it seems. That is, the novel's choral narrative voice undermines the ideology it tries so hard to support, and thus emerges as a metafictional critique of the very reality it is attempting to portray.

This reality is none other than the stance engendered and enforced by Charter capitalism and consumerism - the impulse to utilize and regulate the world's nonhuman and human resources together. Like Warren Finch, the novel's communal narrative voice represents the assimilated other, inculcated with the centrist ideology of conquest and control, interpellated into mistaking drudgery for the pride of the laborer and environmental exploitation as a necessary part of ensuring food security, and incapable of linking this hegemonic will to power with the dire state of the biosphere. In her insightful account of Lee's earlier novel Native Speaker (1995), Michelle Young-Mee Rhee describes how an 
awareness of the stereotyping of Asian-Americans as "the model minority" enables the novel to perform a "metacommentary" (158) on both the Korean-American narrator's idea of himself and the high expectations that have come to envelop Asian-American writers. One might argue that Lee carries this ironic treatment of the model-minority myth over to $O n$ Such a Full Sea, for it is the choral narrator's willingness to assume such a position that makes it both blind to and complicit in the degradation of both community and planet. Such complicity is also evident in the actions of Fan's brother, Oliver, who has been thoroughly indoctrinated into the Charter emphasis on organizational efficiency and material wealth. His penchant for the former is apparent in the astonishing speed and proficiency with which he and Betty construct a home for themselves and, ostensibly, Fan; at the same time, his avarice for the latter means that he willingly betrays his sister in order to finance the expensive new property. Here, Oliver is so much a model of the dominant ideology that he poses a greater threat than those who might be considered "native" to its ways, for, indeed, Fan is saved by other Charter residents, such as Betty, and Oliver's best friend, Vik.

Importantly, Warren's and Oliver's betrayals of their wives and sisters in both novels remind us that the voiceless other is not just a raced other but a gendered other. But, by the end of each narrative, it is apparent that, though this other may be silent, she is not necessarily silenced. That is, voicelessness here is not passivity inasmuch as it is an active critique of voice as discourse and as power. Or, to invoke Gayatri Spivak's memorable question of whether the subaltern might speak, one could say that the raced and gendered subaltern of these texts does not speak, but, then again, nor should she, for her achievement is to ensure that speech itself is rendered suspect. Where Warren and Oliver are assimilated or acculturated into an ideology of oppression, Oblivia and Fan occupy positions that are not just outside this ideology but capable of decentering it. In other words, these are positions of agency — though not, strictly speaking, of power-for, after all, the postmodern techniques of 
magical realism and metafiction dislodge not just the position of power but the notion of power altogether.

Thus, Oblivia's inhabitation of a mute and timeless reality is expressive of an empathy with her land, and a refusal to assume both discourse and power. As Takolander comments, it is not simply that Oblivia's silence "metonymically represent[s] the condition of Aboriginal people in colonial Australia," the novel's "ultimate agenda is ironizing traumatic colonial histories to enable a sovereign future" (117). More than that, it is a reclamation of an ecocentric or, at least, a non-anthropocentric ontology. That Oblivia ends the novel with having journeyed back to her country on foot and having rescued a black swan underlines this: it invokes a rejection of hierarchy and power and an embrace of nonhuman others. What is decentered is not just anthropocentrism but the commitment to centrism itself. Narrative and voice are not so much replaced as destabilized and exposed. Similarly, Fan's defocalized and decentered position functions to subvert the importance of focalization and centering. That her agency occurs, as it were, offstage, with her actions described vicariously and her motives only guessed at, has several important corollaries. It undermines the authority of the choral narrator, who is neither the site of action nor a source of knowledge. Indeed, where first-hand descriptions are made, these are of effects, rather than of causes, such as the quiet protests in the B-Mor community in sympathy with Fan - the appearance of anonymous graffiti and murals, and the trend for shaved heads amongst B-Mor laborers. This curious dislocation of protagonist agency from narratorial omniscience inverts the conventional allocation of power to narrative voice, and assigns authority instead to a quiet heroine.

The dislodging of voice is, of course, particularly significant with regard to the nonhuman. These novels remind us that the relentless search for the "voice" of "nature" is a doomed anthropocentric obsession, a quest born of human vanity. The idea that the nonhuman should or could be rendered in terms of voice stems from a fetishization of voice 
itself, a preoccupation with this human medium as the only way in which "nature" might communicate and be counted. It leads to the fruitless "dilemma," as Catriona Sandilands puts it, of trying to discern "the authentic 'voice' of nature," and results in the problem of how to provide, assume, or assign "authentic speech for nonspeaking nature" (79). By concerning themselves with voicelessness but refusing to correlate it with passivity, these narratives interrogate the valorization of (human) voice, and reveal such an investment to be at the heart of anthropocentric thinking and Anthropocenic damage.

Wright's and Lee's novels undertake a postmodern critique of narrative voice as part of a wider critique of the fallacy of the power of human voice. More importantly, these novels show how the alternative to anthropocentric power is not the appropriation of power but the relentless critique of it. In other words, these climate change novels perform nothing less than the decentering of Anthropos and all its trappings. This, then, is the possibility that postmodernism offers to climate change fiction: narrative that expresses an incredulity toward humans' sense of self-importance, which we are only now coming to understand to be the profoundest and most damaging metanarrative of all.

\section{Works Cited}

Aldea, Eva. Magical Realism and Deleuze: The Indiscernibility of Difference in Postcolonial Literature. London: Continuum, 2011. Print.

Atwood, Margaret. MaddAddam. New York: Nan A. Talese-Doubleday, 2013. Print.

---. Oryx and Crake. 2003. London, Virago, 2004. Print.

---. The Year of the Flood. 2009. London: Virago, 2010. Print. 
Biddle, Nicholas, and Sarah Prout. "The Geography and Demography of Indigenous Temporary Mobility: An Analysis of the 2006 Census Snapshot.” Journal of Population Research 26 (2009): 305-26. Print.

Clark, Timothy. Ecocriticism on the Edge: The Anthropocene as a Threshold Concept. London: Bloomsbury, 2015. Print.

Clarke, Jim. "Reading Climate Change in J. G. Ballard.” Critical Survey 25.2 (2013): 7-21. Print.

Curtin, Deane. Environmental Ethics for a Postcolonial World. Lanham, MD: Rowman and Littlefield, 2005. Print.

D'haen, Theo L. "Magical Realism and Postmodernism: Decentering Privileged Centers." Magical Realism: Theory, History, Continuity. Ed. Lois Parkinson Zamora and Wendy B. Faris. Durham, NC: Duke UP, 1995. 191-208. Print.

Demos, T. J. Decolonizing Nature: Contemporary Art and the Politics of Ecology. Berlin: Sternberg Press, 2016. Print.

Faris, Wendy B. "Scheherazade's Children: Magical Realism and Postmodern Fiction." Magical Realism: Theory, History, Continuity. Ed. Lois Parkinson Zamora and Wendy B. Faris. Durham, NC: Duke UP, 1995. 163-90. Print.

Franco, Jean. "What's Left of the Intelligentsia? The Uncertain Future of the Printed Word." NACLA Report on the Americas 28.2 (1994): 16-21. Print.

Haraway, Donna J. Staying with the Trouble: Making Kin in the Chthulucene. Durham, NC: Duke UP, 2016. Print.

Holgate, Ben. "Unsettling Narratives: Re-evaluating Magical Realism as Postcolonial Discourse through Alexis Wright's Carpentaria and The Swan Book." Journal of Postcolonial Writing 51.6 (2015): 634-47. Print. 
Huggan, Graham, and Helen Tiffin. Postcolonial Ecocriticism: Literature, Animals, Environment. London: Routledge, 2010. Print.

Lee, Chang-rae. Native Speaker. New York: Riverhead Books, 1995. Print.

---. On Such a Full Sea. 2014. London: Abacus, 2015. Print.

Leyshon, Cressida. “The Chorus of 'We': An Interview with Chang-rae Lee.” The New Yorker. 6 January 2014. Web.

Lyotard, Jean-François. The Postmodern Condition: A Report on Knowledge. Trans. Geoff Bennington and Brian Massumi. Minneapolis: U of Minnesota P, 1984. Print. Mayer, Sylvia. "Explorations of the Controversially Real: Risk, the Climate Change Novel, and the Narrative of Anticipation." The Anticipation of Catastrophe: Environmental Risk in North American Literature and Culture. Ed. Sylvia Mayer and Alexa Weik von Mossner. Heidelberg: Universitätsverlag Winter, 2014. 21-37. Print.

Mehnert, Antonia. Climate Change Fictions: Representations of Global Warming in American Literature. London: Palgrave Macmillan, 2016. Print.

Moore, Jason W. "Introduction: Anthropocene or Capitalocene? Nature, History, and the Crisis of Capitalism." Anthropocene or Capitalocene? Nature, History, and the Crisis of Capitalism. Oakland, CA: PM Press, 2016. 1-13. Print.

Morton, Timothy. Hyperobjects: Philosophy and Ecology after the End of the World. Minneapolis: U of Minnesota P, 2013. Print.

Moylan, Tom. Scraps of the Untainted Sky: Science Fiction, Utopia, Dystopia. Boulder, CO: Westview, 2000. Print.

Nicol, Bran. The Cambridge Introduction to Postmodern Fiction. Cambridge: Cambridge UP, 2009. Print.

Plumwood, Val. Environmental Culture: The Ecological Crisis of Reason. London: Routledge, 2002. Print. 
---. Feminism and the Mastery of Nature. London: Routledge, 1993. Print.

Rhee, Michelle Young-Mee. “'Greater Lore': Metafiction in Chang-rae Lee’s Native Speaker.” MELUS 36.1 (2011): 157-76. Print.

Rigby, Kate. “The Poetics of Decolonization: Reading Carpentaria in a Feminist Ecocritical Frame." International Perspectives in Feminist Ecocriticism. Ed. Greta Gaard, Simon C. Estok, and Serpil Oppermann. New York: Routledge, 2013. 120-36. Print.

Sandilands, Catriona. The Good-Natured Feminist: Ecofeminism and the Quest for Democracy. Minneapolis: U of Minnesota P, 1999. Print.

Slemon, Stephen. "Magic Realism as Post-colonial Discourse." Canadian Literature 116 (1988): 9-24. Print.

Spivak, Gayatri Chakravorty. "Can the Subaltern Speak?” Marxism and the Interpretation of Culture. Ed. Cary Nelson and Lawrence Grossberg. Urbana: U of Illinois P, 1988. 271313. Print.

Suvin, Darko. Metamorphoses of Science Fiction: On the Poetics and History of a Literary Genre. New Haven, CT: Yale UP, 1979. Print.

Takolander, Maria Kaaren. “Theorizing Irony and Trauma in Magical Realism: Junot Díaz’s The Brief Wondrous Life of Oscar Wao and Alexis Wright's The Swan Book." Ariel: A Review of International English Literature 47.3 (2016): 95-122. Print.

Trexler, Adam. Anthropocene Fictions: The Novel in a Time of Climate Change. Charlottesville: U of Virginia P, 2015. Print.

---, and Adeline Johns-Putra. "Climate Change in Literature and Literary Criticism." WIREs Climate Change 2 (2011): 185-200. Print.

Warnes, Christopher. Magical Realism and the Postcolonial Novel: Between Faith and Irreverence. Houndmills, Basingstoke: Palgrave Macmillan, 2009. Print. 
Waugh, Patricia. Metafiction: The Theory and Practice of Self-Conscious Fiction. London: Routledge, 1984. Print.

Winterson, Jeanette. The Stone Gods. 2007. London: Penguin, 2008. Print.

Wright, Alexis. Carpentaria. 2006. London: Constable, 2016. Print.

---. “A Question of Fear.” Tolerance, Prejudice, and Fear. Ed. Gideon Haigh, Christos

Tsiolkas, and Alexis Wright. Crows Nest, NSW: Allen and Unwin, 2008. 129-69. Print.

---. The Swan Book. 2013. London: Constable, 2016. Print.

\title{
Notes
}

\begin{abstract}
${ }^{1}$ I thus adopt the term "Anthropocene," rather than more recent formulations, such as "capitalocene" and "Chthulucene," since it captures the tension between the anthropocentric thinking that has led to environmental crisis on the one hand and the ecocentric (but still human-initiated) thinking that might begin to redress that crisis on the other. The capitalocene identifies the ways in which human systems, such as capitalism, have never been separate from nonhuman systems, no matter how much they purport to be; see, for example, Jason W.
\end{abstract} Moore on how "humans — and human organizations (e.g. empires, world markets) — fit within the web of life, and vice versa" (4-5). Meanwhile, a concept such as Chthulucene names a collaborative, co-creative vision for the future that might undo the damage signaled by anthropocentric thinking; see Donna Haraway (30-57). However, as a more capacious label, "Anthropocene" encompasses, uneasily but productively, both this potential for ecocentric action and the dangers of anthropocentric thinking.

${ }^{2}$ Particularly early examples of climate change fiction take inspiration from earlier science fiction representations of disastrous global climatic conditions by authors such as J. G. Ballard, Brian Aldiss, Frank Herbert, and H. G. Wells. Trexler has labeled these a 
"considerable archive of climate change fiction" (8) and Jim Clarke "proto-climate-change" (8) fiction. 